\title{
Assessing Impacts of Payment for Forest Environmental Service Policy in Hoa Binh Province, Vietnam
}

\author{
Nguyen Phuong Le ${ }^{1}$, Mai Quyen ${ }^{2}$, Nguyen Mau Dung ${ }^{3}$ \\ ${ }^{1,3}$ Vienam National University of Agriculture \\ ${ }^{2}$ Vietnal National University of Forestry
}

\begin{abstract}
The policy of payment for forest environmental services (PFES) has been implemented in Vietnam since 2011 and in Hoa Binh province since 2013. This policy has had certain impacts on improvement of local people living standard as well as on forest protection and development. Based on secondary and primary information collected in Mai Chau district, Da Bac district and Hoa Binh city, this paper analyzes the economic, social and environmental impacts of PFES on the forestry sector in general and forest owners in particular. The study showed that although money that was received from PFES by households was very small in their overall income, revenue of Commune People's Committees communities was so large that it could help them to purchase equipment for forest protection and development. Thanks to PFES, forest area and forest cover rate of Hoa Binh province have been markedly increased.
\end{abstract}

KEYWORD: Impact, Hoa Binh, Policy, PFES

\section{INTRODUCTION}

Forest environmental services are considered as public goods (where market failures exist), i.e. the beneficiaries of indirect values which are generated by forests do not have to pay. People who have been providing, conserving and developing these services have not received any payment for their works, hence they have no incentive to plant and protect forests [11]. In order to protect the existing forest area, to improve forest quality, and to increase the contribution of the forestry sector to the national economy as well as to reduce the state's budget burden for investment in the forestry sector and to ensure livelihood of forest-based people, Vietnamese government has decided to adopt policy of payment for forest environmental services as a new financial mechanism to mobilize resources for forestry sector [6].

In 2004, Vietnam initiated some pilot studies to build a foundation for a national PFES program by the forest ecosystem. Vietnam was the first country in Asia to launch a national program on the PFES scheme under Decision No. 380/QD-TTg in 2008 and the Decree 99/2010/ND-CP in 2010 (Decree 147/2016/ND-CP in 2016, amending and supplementing some articles of the Government's Decree 99) (Pham et al., 2013). The PFES policy has been one of ten greatest successes of forestry sector in Vietnam during 2010-2020. Thanks to the implementation of this policy, the forest area paid by PFES has increased from nearly 1.4 million hectares (in 2011) to over 6.8 million hectares (by 2020), of which special-use forests, protection forests and production forests account for $18.8 \%, 40.5 \%, 40.7 \%$, respectively. The total amount of PFES payments reached VND 16,758 billion, accounting for $18.2 \%$ of the total investment in forestry sector. This is a stable and sustainable financial source which significantly contributes to improving the production value of forestry industry, promoting socio-economic development, reducing the burden on the state budget in forestry development strategy. In particular, the effectiveness of policy has changed people's awareness in forest management and protection, then created new livelihood strategies for local people who used to live on forest [1].

Located in the Nothwest of Vietnam, Hoa Binh province has implemented PFES policy since 2013 followed by Decree No. 99/2010/ND-CP. By the end of 2019, the amount of money collected from PFES in whole province was VND 131,351.96 million; the amount paid to forest owners was VND 93,590.82 million. At the same time, the forest area which has been covered by PFES was 122,450.28 ha, accounting for $47.55 \%$ of the province's total forest area (Hoa Binh Fund for Forest Protection and Development, 2019). PFES policy has had a positive impacts including: Upgrading awareness of forest owners, enhancing forest protection, improving people's lives in remote areas, and increasing forest owners' income. Although PFES has brought about such 


\section{International Journal of Current Science Research and Review}

ISSN: 2581-8341

Volume 04 Issue 06 June 2021

DOI: 10.47191/ijcsrr/V4-i6-09, Impact Factor: 5.825

IJCSRR@ 2021

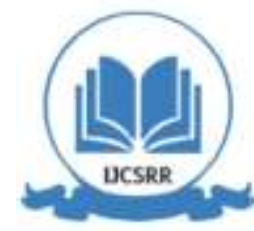

www.ijcsrr.org

achievements, during the past decade, very few scientific studies have been conducted to assess the overall impacts of the policy in Vietnam ([2], [10], [17], [13]) and furthermore, there were limited empirical evidences on forest quality outcomes [9].

Tran et al. have a preliminary assessment of the economic, social and environmental impacts of PFES pilot program in Lam Dong [13], while Pham et al. performed an impact assessment of PFES in Son La [8]. Recently, Pham et al. (2020) evaluated the economic and social impacts of PFES in Cat Tien National Park [9]. Up to now, there have been no research that was conducted to assess the economic, social and environmental impacts of PFES in Hoa Binh province. Therefore, this article aims to fill this gap by providing an analysis of impacts of PFES policy on economic, social and environmental aspects at different levels (provincial community and household) Hoa Binh province.

\section{METHODS}

Hoa Binh city, Da Bac and Mai Chau districts have been selected to conduct the research because these are localities where PFES had been earliest implemented in Hoa Binh province. Further, the groups of forest owners in these districts are very diverse (households, communities, Commune People's Committees and other organizations).

Secondary information has been collected from different sources such as reports of provincial Forest Protection and Development Fund (FPDF), provincial statistical yearbooks, provincial socio-economic development plans, reports of hydropower plants and water plants, published scientific reports. Primary information and data have been collected from forest owners, including: 400 households receiving PFES payments, 70 households not receiving PFES payments, 8 forest owners as organizations, 34 forest owners as communities and 32 forest owners as Commune People's Committees.

Descriptive statistics and comparison have mainly used in data analysis. The comparisons were made over time, between the groups that have been paid by PFES and the ones that have not been paid. Apart from statistical and surveyed data, qualitative level assessment (positive change, no change, or negative change) was applied in analysis. According to Pham et al., [6] PFES impacts could be assessed at provincial, district, commune and village levels, mostly based on indicators published by Vietnam Forest Protection and Development Fund (VNFF). However, in this research, the impacts were mainly evaluated at provincial and household levels grouped into three themes: economic, social, and environmental aspects. Provincial level impacts were assessed based on criteria collected from statistical reports, such as forest cover, state investment in forest sector and quantity and quality of water in hydropower reservoirs, and the numbers of beneficiaries. At household level, the impacts were investigated based on household's income and expenditure, local people's livelihood activities and their awareness of forest protection. The analytical indicators have been shown in Table 1.

Table I: Indicators for assessing impacts of PFES policy

\begin{tabular}{|c|c|}
\hline \multicolumn{2}{|l|}{ Indicators for assessing impacts } \\
\hline Economic impact indicators & $\begin{array}{ll}\text { - } & \text { Structural investment in forestry sector } \\
\text { - } & \text { Amount of money recieved by forest owner/year } \\
\text { - } & \text { Household income } \\
\text { - } & \text { Household expenditure }\end{array}$ \\
\hline Social impact indicators & $\begin{array}{l}\text { - } \quad \text { Quantity of district, commune and household paid by PFES } \\
\text { - } \quad \text { Changes in forest-based livelihood activities } \\
\text { - } \quad \text { Awareness of local people of forest protection }\end{array}$ \\
\hline Environmental impact indicatios & $\begin{array}{ll}\text { - } & \text { Rate of covered forest area } \\
\text { - } & \text { Quantity and quality of water in hydropower reservoir }\end{array}$ \\
\hline
\end{tabular}

\section{RESULTS AND DISCUSIONS}

\subsection{PFES policy implementation in Hoa Binh province}

Hoa Binh province has implemented PFES since 2013, up to June 2019, the province has 13 basins that made PFES payments in 7 districts and cities including: Da Bac, Mai Chau, Tan Lac, Lac Son, Cao Phong, Ky Son, Hoa Binh city, with a total forest area providing PFES 122450.28 ha, achieving an average growth rate of $107.5 \%$ /year. Two districts with the largest forest area are Da Bac (36.74\%) and Mai Chau (30.66\%), Lac Son district has the smallest area (2.48\%). The forest area providing PFES of the districts has been determined by the area in the basins of hydropower plants and fresh water plants. Of the total area paid for 


\section{International Journal of Current Science Research and Review}

ISSN: 2581-8341

Volume 04 Issue 06 June 2021

DOI: 10.47191/ijcsrr/V4-i6-09, Impact Factor: 5.825

IJCSRR@ 2021

Www.ijcsrr.org

PFES, up to $70.99 \%$ is natural forest, up to $49.14 \%$ is protection forest and $12.13 \%$ is special-use forest (this area is allocated to management units).

According to Decree No. 99/2010/ND-CP, buyers in Hoa Binh have been identified as water supply companies, hydropower plants (not tourism companies and aquaculture businesses yet), and sellers as forest owners (organizations, households, forest management units, communities, and Commune People's Committee) with forests allocated or leased by the State. To be paid, the sellers have to manage properly in line with the forest protection and assigned plan by competent state agencies. Participation is mandatory, as buyers and sellers are identified by law and must take part in the program. Government sets the level of payment, and VNFF signs contracts with buyers that set out the amounts they must pay for forest environmental services. Payments are disbursed for the maintenance of existing forest cover as a proxy for forest environmental services. Hoa Binh FPDF signs contracts with service buyers and collects payments for services supplied within the province. The fund also prepares payment plans, monitors and releases payments to service suppliers and submits periodic reports to the VNFF.

By the end of 2019, the amount of PFES collected by Hoa Binh was VND 131,351.96 million, accounting for 0.94\% of whole country's PFES. Of which, VNFF collected VND 119,637.16 million (accounting for 91.08\%) while FPDF collected VND 11,714.80 million (accounting for 8.92\%). The PFES value in 2018 and 2019 nearly doubled compared to 2017 due to an increase in payment level from $20 \mathrm{VND}$ to $36 \mathrm{VND}$ for each commercial kwh of hydroelectric power plants and from $40 \mathrm{VND} 52$ for each $\mathrm{m}^{3}$ of water of fresh water plants according to Decree 147/2016/ND-CP.

Table 2: Forest areas covered by PFES in Hoa Binh province (up to 2018)

\begin{tabular}{lll}
\hline Criteria & Forest area covered by PFES (ha) & Percent \\
\hline Total forest area covered by PFES & $\mathbf{1 2 2 . 4 5 0 , 2 8}$ & $\mathbf{1 0 0}$ \\
1. Based on forest origins & & 70.99 \\
- Natural forest & $86,925.90$ & 29.01 \\
- Planted & $35,524.38$ & 49.14 \\
2. Based on forest functions & & 12.13 \\
- Protection forest & $60,172.33$ & 36.27 \\
- Special-used forest & $14,851.93$ & 2.46 \\
- Production forest & $44,410.31$ & 1.71 \\
- Others & $3,015.71$ & 12.13 \\
3. Based on forest owners & & 1.68 \\
- Protection forest management unit & $2,094.09$ & 39.55 \\
- Special-used forest management unit & $14,855.26$ & 9.47 \\
- State-owned forest enterprise & $2,054.75$ & 32.63 \\
- Households & $48,428.80$ & 2.83 \\
- Communities & $11,590.40$ & \\
- Commune People's Committee & $39,957.27$ & \\
- Other economic organizations & $3,469.66$ & \\
\hline
\end{tabular}

Source: Provincial Fund Forest Protection and Development, 2019

\subsection{Impacts of PFES at different levels in Hoa Binh province}

3.2.1 Economic impacts

Pham et al. [8, 9] and Thu-Ha et al. [11] have assessed PFES impacts based on indicators such as forest cover, forest protection, the number of households contracted to protect the forest, the amount of money received/day for forest protection patrol, the proportion of income from PFES in the total income of the household, the change in local livelihoods. Duong \& de Groot identified PFES impacts on community-level forest management, particularly changes in the forest patrol groups, trespass and fire prevention, and the effectiveness of forest protection rules [2]. Whereas this paper examined the economic impacts at both provincial and forest owner levels, especially the household. At provincial level, economic impact was assessed by financial contribution to forestry sector while at household level it was measured by annual amount of money received by a forest owner (mostly household) and changes in household income and expenditure. 


\section{International Journal of Current Science Research and Review}

ISSN: 2581-8341

Volume 04 Issue 06 June 2021

DOI: 10.47191/ijcsrr/V4-i6-09, Impact Factor: 5.825

IJCSRR@ 2021

WWw.ijcsrr.org

Table 3: Financial sources invested in forest protection and development in Hoa Binh province in period $2011-2018$

\begin{tabular}{|c|c|c|c|c|c|c|}
\hline \multirow{3}{*}{ Year } & \multicolumn{5}{|c|}{ Financial sources invested in forest protection and development (Mil VND) } & \multirow{2}{*}{$\begin{array}{l}\text { PFES in Total } \\
(\%)(5 / 1)\end{array}$} \\
\hline & Total & State budget & Other sources & Reforestation & PFES & \\
\hline & $(1)$ & (2) & $(3)$ & (4) & $(5)$ & $(6)$ \\
\hline 2011 & $25,290.55$ & $8,881.67$ & - & - & $11,092.43$ & 43.86 \\
\hline 2012 & & $5,316.45$ & - & - & & \\
\hline 2013 & $13,891.91$ & 987.80 & - & - & $12,904.11$ & 92.89 \\
\hline 2014 & $17,132.79$ & 4,400 & - & 36 & $12,696.79$ & 74.11 \\
\hline 2015 & $21,408.48$ & 4,400 & - & 759 & $16,249.48$ & 75.90 \\
\hline 2016 & $27,336.40$ & 11,600 & $1,265.71$ & 125 & $14,345.69$ & 52.48 \\
\hline 2017 & $52,319.01$ & 34,800 & $1,265.71$ & 100 & $16,153.30$ & 30.87 \\
\hline 2018 & $67,236.20$ & 36,000 & $1,265.71$ & $1,315.82$ & $28,654.67$ & 42.62 \\
\hline Total & $224,615.33$ & $106,385.92$ & $3,797.12$ & $2,335.82$ & $112,096.47$ & 49.91 \\
\hline
\end{tabular}

Source: Forest Protection Department \& FPDF, Hoa Binh province, 2019

According to Pham et al., PFES has contributed to the forestry sector in different ways: (i) Contributing funds to forest protection contracts; (ii) Financial support for paying labor wages, operating costs, and capacity building for forestry activities; (iii) Providing revenue for forest management units, conservation areas, national parks and state-owned forestry enterprises; (iv) Contributing to infrastructure and community development programs [8]. The financial supports for forestry development in Hoa Binh province have been mainly from the self-financed sources of enterprises, households and individuals and investment supports from the state budget.

Table 3 shows that while financial supports from the state budget and other sources have insignificantly increased, PFES contribution to provincial fund for forest protection and development increased very quickly (in 2018 increased by $258.32 \%$ compared to 2011 - 2012 period and $176.34 \%$ compared to 2015). By the end 2018, PFES contributed $49.1 \%$ to total investment in fund for forest protection and development which was higher than the national average (22\%). Additionally, the amount of money collected from PFES was higher than state budget investment in the forestry sector in Hoa Binh province.

PFES contributed finance not only to forestry sector, but also to forest owners. PFES payment rates were calculated as the total PFES fees paid by buyers divided by the total area of forest protected. Using this method of calculation, the protection and special-use forest management units received the largest PFES per owner, and the smallest was belonged to household. PFES received by households accounted for $34.62 \%$ of total, but the PFES per household was only VND 369.38 thousands. This was such a small number that it could not achieve the goal of poverty eradication. The reason is the fact that there are a number of households while their forest area is too small (averagely 2.2 ha/household, but most of households were allocated less than 1 ha). Although Commune People's Committees (CPCs) were not holders who were allocated forest by Forest Law (instead, they were temporarily assigned by the State to manage and protect forest), they received the highest value and proportion of PFES in Hoa Binh province.

Table 4: PFES received by forest owners in 2018

\begin{tabular}{llll}
\hline \hline Forest owner & $\begin{array}{l}\text { Quantity } \\
\text { of owner }\end{array}$ & $\begin{array}{l}\text { Total PFES } \\
\text { (VND Thousands) }\end{array}$ & $\begin{array}{l}\text { PFES/owner } \\
\text { (VND Thousands) }\end{array}$ \\
\hline 1. Protection forest management unit & 1 & $725,622.93$ & $725,622.93$ \\
2. State-owned enterprise & 1 & $372,074.29$ & $372,074.29$ \\
3. Special-used forest management unit & 4 & $2,353,529.82$ & $588,382.46$ \\
4. Households & 21,970 & $8,115,335.84$ & 369.38 \\
5. Communities & 112 & $1,534,468.35$ & $13,700.61$ \\
6. CPCs & 104 & $9,259,412.52$ & $89,032.81$ \\
7. Other organizations & 20 & $1,079,340.20$ & $53,967.01$ \\
\hline
\end{tabular}

Source: FPDF, Hoa Binh province, 2019 


\section{International Journal of Current Science Research and Review}

ISSN: 2581-8341

Volume 04 Issue 06 June 2021

DOI: 10.47191/ijcsrr/V4-i6-09, Impact Factor: 5.825

IJCSRR@ 2021

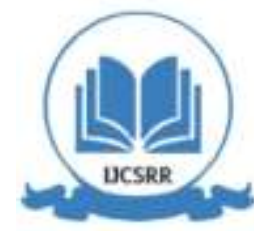

www.ijcsrr.org

Forest income of households receiving PFES is very low, mainly from collecting bamboo shoots and firewood. Most of surveyed households have very diverse livelihood strategies and multiple income sources, including agriculture, fishing, small trade, workers, migrant labors and forestry. PFES occupies only a small portion of household's overall income $(0.43 \%)$ and contributes $4.5 \%$ of income from forest. When asked about the level of PFES payment, only $1.25 \%$ of survey respondents rated it as high, $14.25 \%$ as moderate and up to $84.5 \%$ of them said it was so low that it could not encourage them to protect the forest. This finding was quite similar to what Pham et al. (2018) investigated in Son La. According to these authors, the impact of PFES on people's income was so low that it has not created real motivation for people to participate in forest protection and development.

Table 5: Incomes of households paid and unpaid by PFES

\begin{tabular}{llll}
\hline Indicators & $\begin{array}{l}\text { Value } \\
\text { (VND Mil/household) }\end{array}$ & & $\begin{array}{l}\text { Standard } \\
\text { deviation (Std) }\end{array}$ \\
\hline \multirow{2}{*}{ Paid households } & Total income & 75,89 & 57,35 \\
& Forest income & 7,34 & 10,54 \\
\multirow{2}{*}{ Unpaid households } & Total income & 93,7 & 91,28 \\
& Forest income & 12,43 & 61,18 \\
T- test (P- value) & Total income & $0,000 * * *$ & - \\
& Forest income & $0,000 * * *$ & - \\
\hline
\end{tabular}

Source: Survey data, $2018(* * *$ denotes $1 \%$ level of significance)

When comparing with and without PFES paid households by T-test with statistical significance at $1 \%$, it was indicated that both overall and forest incomes of households who have not been paid by PFES were higher than paid households'. This finding was supported by what was investigated by Pham et al. and Thu-Ha et al. (2018). The reason is the fact that households paid by PFES are mostly poor belonging to ethnic minority group and located in remote areas $(77.5 \%$ of the households receiving PFES payments in Hoa Binh are ethnic minorities). Almost all households who were not paid by PFES have better economic conditions because their income was mainly generated from planted forest and fruit trees grown in forest land. The amount of money received/year was very small, therefore most households $(77.75 \%)$ used it for daily expenses, only $13.25 \%$ of respondents invested in production such as buying seedlings.

\subsubsection{Social Impacts}

PFES social impacts were assessed by the Government of Vietnam based on the number of individual households and communities paid under the program, the number of households (particularly the poor) that received benefits from PFES, and the engagement in forest conservation schemes linked to PFES. Pham et al. examined PFES social impacts on poverty reduction and ethnic minority people's participation in forest protection and development programs [9]. In this article, PFES social impacts have been analyzed based on three criteria: (i) the participation of organizations, (ii) changes in people's perception of forest protection and (iii) development and changes in their forestry activities.

According to Hoa Binh FPDF, by the end of 2018, there were 7 districts/cities (accounting for $70 \%$ of district-level units), 104 communes/wards/towns (accounting for $68.8 \%$ of commune-level units) with 21,970 households receiving PFES payments, of which 17,576 ethnic minority households (accounting for 80\%) and 1,822 poor households (accounting for $8.3 \%$ ) and 1,952 pro-poor households (accounting for $8.9 \%$ ).

Table 6. Changes in the number of visits for forest protection since PFES

\begin{tabular}{lllllll}
\hline Forest owners & Positive & \multicolumn{2}{c}{ No change } & \multicolumn{2}{c}{ Negative } \\
& Times & Percent & Times & Percent & Times & Percent \\
\hline 1. Organizations and CPCs $(\mathrm{n}=40)$ & 18 & 45,00 & 22 & 55,00 & 0 & 0 \\
2. Households $(\mathrm{n}=400)$ & 109 & 27,25 & 284 & 71,00 & 7 & 1,75 \\
3. Communities $(\mathrm{n}=34)$ & 13 & 38,23 & 21 & 61,77 & 0 & 0 \\
\hline
\end{tabular}

Source: Survey data, 2018 


\section{International Journal of Current Science Research and Review}

ISSN: 2581-8341

Volume 04 Issue 06 June 2021

DOI: 10.47191/ijcsrr/V4-i6-09, Impact Factor: 5.825

IJCSRR@ 2021

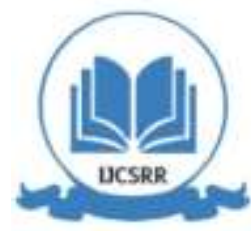

www.ijcsrr.org

According to surveyed forest owners, their awareness of forest protection has positively changed due to PFES. However, it was witnessed that forest owners' awareness has slightly improved because their patrols and forest protection visits had no change (55\% for organizations and CPCs, $71 \%$ for households and $61.77 \%$ for communities). Even though, thanks to improvement of awareness of forest protection, forestry activities of households have been changed in a positive direction. The number of households converting land and illegal logging decreased while those who participated in preventing others from forest burning and illegal forest exploitation increased. There was a difference between ethnic groups in changing their forestry activities when they involved in PFES program (Chi-Square tests showed statistical significance at 1\%). Specifically, forestry activities have changed more positively in groups of Kinh and Muong in comparison with Dzao and Tay (Table 7). This finding was different from what has found out by Duong $\&$ de Groot [2]. For these two authors, a higher PFES disbursement tended to report a higher number in changed forest management actions in a positive direction Duong \& de Groot [2].

Table 7: Changes in forestry activities of households paid by PFES

\begin{tabular}{|c|c|c|c|c|c|}
\hline \multirow{2}{*}{ Forestry activities } & \multicolumn{5}{|c|}{ Ethnic groups $(\%)(n=400)$} \\
\hline & Kinh & Muong & Thai & Dzao & Tay \\
\hline Stopping forest land conversion ${ }^{1}$ & 66.7 & 60.8 & 50.9 & 31.2 & 30 \\
\hline No illegal logging ${ }^{2}$ & 62.2 & 57.5 & 52.8 & 31.2 & 44 \\
\hline No collecting firewood ${ }^{3}$ & 55.6 & 47.5 & 45.4 & 25 & 26 \\
\hline Preventing others from illegal forest exploitation ${ }^{4}$ & 66.7 & 53.3 & 48.1 & 28.1 & 38 \\
\hline Preventing others from burning forest ${ }^{5}$ & 56.7 & 55.8 & 50.9 & 34.4 & 46 \\
\hline
\end{tabular}

Source: Survey data, 2018

Note: (1) Pearson's chi-square test 32,808; P-value: 0,00; (2) Pearson's chi-square test 35,062; P-value: 0,00; (3) Pearson's chi-square test 31,236; P-value: 0,00; (4) Pearson's chi-square test 36,469; P-value: 0,00; (5) Pearson's chi-square test 38,841; Pvalue: 0,00 .

\subsubsection{Environmental Impacts}

The environmental impacts of PFES in this study have been assessed on such criteria as: forest cover rate and quantity and quality of water in hydropower reservoirs. The province's forest cover rate has continuously increased from $46 \%$ in 2010 (when the PFES policy has not been implemented) to $51.5 \%$ in 2018 which were higher than the average rate of Northwest region and whole country (Table 8). Apart from forest cover, PFES significantly contributed to hydropower sector which could be measured by criteria such as reducing sedimentation, retaining water for power generation in the dry season, and regulating flows in the dry and flood seasons ([5], [15], [16]).

Table 8. Rate of forest cover in Hoa Binh province in the period 2010-2018

Unit: \%

\begin{tabular}{|c|c|c|c|c|c|c|c|}
\hline \multirow{2}{*}{ Location } & \multirow{2}{*}{2010} & \multirow{2}{*}{2012} & \multirow{2}{*}{2014} & \multirow{2}{*}{2018} & \multicolumn{3}{|c|}{ "Comparison } \\
\hline & & & & & $2012 / 2010$ & $2014 / 2012$ & $2018 / 2014$ \\
\hline Hoa Binh & 46.0 & 49.3 & 48.9 & 51.5 & 107.17 & 99.19 & 105.32 \\
\hline Northwest region & 42.2 & 44.6 & 43.64 & 44.57 & 105.69 & 97.85 & 102.13 \\
\hline Whole country & 39.5 & 40.7 & 40.4 & 41.7 & 103.04 & 99.26 & 103.22 \\
\hline
\end{tabular}

Source: General Statistical Office (2010 - 2018)

Water holding efficiency of the forest has been improved with the increase of forest cover rate. Water retention efficiency for Hoa Binh hydropower reservoir is $3397 \mathrm{~m} 3 / \mathrm{ha}$, much higher than whole country average. In the condition of small rainfall (about $1000 \mathrm{~mm}$ ) and relatively flat terrain (about 5 degrees), it is possible to reduce amount of sediment deposited in the lakes on average from 10.6 tons/ha/year when the forest cover is $0 \%$ to 0.5 tons/ha/year when the forest coverage reaches to $100 \%$. Under conditions of heavy rainfall (about $2500 \mathrm{~mm}$ ) and relatively steep terrain (about 25 degrees), it is possible to reduce the amount of sediment 


\section{International Journal of Current Science Research and Review}

ISSN: 2581-8341

Volume 04 Issue 06 June 2021

DOI: 10.47191/ijcsrr/V4-i6-09, Impact Factor: 5.825

IJCSRR@ 2021

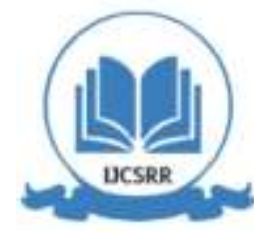

www.ijcsrr.org

deposited in lakes by an average of 11.5 tons/ha/year when forest cover is $0 \%$ to 3.4 tons/ha/year when forest cover is $100 \%$. In Northern Vietnam, one ha of forest can prevent amount 6.95 tons/ha/year of sediment, of which the forest in the basin of Hoa Binh hydropower reservoir can prevent 8.1 tons/ha/year [16].

Minh Duc Nguyen et al. quantified water output, water supply value for hydroelectricity production, and reduced sedimentation in reservoir beds of hydropower plants in the Northwest region from 2010 to 2020 based on forest land use, forest cover and other conditions of forest ecosystems [3]. The total amount of water supplied to 4 hydropower plants in the Northwest region for forests under 3 different forest governance scenarios (State-based, household/individual and community-based) was more than 22,137.60 billion m3, of which Hoa Binh hydropower plant was more than 9755.30 billion m3. The total value of water supply for hydroelectricity production for forests under the three scenarios mentioned above was more than 157.3 million USD, of which Hoa Binh hydropower plant was more than 78.8 million USD. Forests in the Northwest has the potential to reduce sedimentation from 18.26 tons/ha/year in 2010 to less than 18 tons/ha/year in 2020. Annual benefits from sediment reduction for management scenario State-based forest governance would be about one million USD/year and community-based forest governance would be about 0.9 million USD/year.

In summary, PFES payments contributed to an increase in forest area and quality, which in turn helped to increase quantity and quality of hydropower reservoirs and to reduce the cost of dredging and sedimentation of the reservoir. The results of in-depth interviews with representatives of hydropower plants in Hoa Binh province witnessed that thanks to PFES policy, watershed forests became better protected, thereby helping to maintain the operation of hydropower plants in a sustainable manner.

\section{CONCLUSION}

It can be said that PFES policy has created positive impacts on the forest environment, contributed to income of forest owners, raised the awareness and commitment of the parties to the protection and development of the forest. For economic aspect, although the contribution of money received from PFES to overall income of household was very small, the contribution of PFES to revenue of the CPCs and the communities were so large that it could help them to equip facilities for forest protection and development, then to support for livelihood enhancement. However, the rate of PFES payments used for rural infrastructure development in Hoa Binh was very low. In the coming years, FPDF should pay attention and provide timely guidance so that forest owners can identify reasonable spending structure. On the social side, since the implementation of PFES policy, people's awareness and commitment to forest protection and development in the study areas have been improved, especially awareness of ethnic minorities in difficult areas. In terms of environmental impacts, the forest area has been increased on a provincial scale, the forest cover rate has markedly increased. In addition, the number of deforestation cases and the area of forest cleared across the province decreased. As for the effects of PFES on quantity and quality of water, it is necessary to collect data over a long period and to coordinate and share information among stakeholders. In this study, information was mainly based on the results of published studies.

\section{REFERRENCES}

1. Bao Han (2020). Implementation of payment for forest environmental services: Integration with livelihood development. Accessed from https://daibieunhandan.vn/long-ghep-voi-phat-trien-sinh-ke-dimsh8olg6-50838 Dated $18^{\text {th }}$ May 2021.

2. Duong, N. T. \& de Groot, W. T. (2020). The impact of payment for forest environmental services (PFES) on communitylevel forest management in Vietnam. Forest Policy and Economics, 113, 102135. doi: https://doi.org/10.1016/j.forpol.2020.102135.

3. Minh Duc Nguyen, Tiho Ancev \& Alan Randall (2018). Forest governance and economic values of forest ecosystem services in Vietnam. Land Use Policy. https://doi.org/10.1016/j.landusepol.2018.03.028.

4. Ministry of Agriculture and Rural Development (2018). The report for 8 years of Implementation of PFES in the period 2008 - 2018.

5. Nguyen Phuc Tho \& Tran Quang Bao (2017). Valuing of forest environmental services for hydropower basins in Vietnam. Journal of Agriculture and Rural Development. Vol (15):145 - 152. Assessed from http://www.tapchikhoahoc nongnghiep.vn /vi/news/CacsoTapchithuongky/TapchiNong-nghiep-va-Phat-trien-nong-thon-so-15-2017-135 Dated $3^{\text {rd }}$ March 2020. 


\section{International Journal of Current Science Research and Review}

ISSN: 2581-8341

Volume 04 Issue 06 June 2021

DOI: 10.47191/ijesrr/V4-i6-09, Impact Factor: 5.825

IJCSRR@ 2021

www.ijcsrr.org

6. Pham Thu Thuy, Ngo Ha Chau, Dao Thi Linh Chi, Hoang Tuan Long, Micah R. Fisher (2020). The politics of numbers and additionality governing the national Payment for Forest Environmental Services scheme in Vietnam: A case study from Son La province. Forest and Society. Vol. 4(2): 379-404.

7. Pham Thu Thuy T, Bennett K, Vu T P, Brunner J, Le Ngoc D \& Nguyen D T. (2013). Payments for forest environmental services in Vietnam: from policy to practice. CIFOR Occasional Paper, (93).

8. Pham Thu Thuy, Dao Thi Linh Chi, Hoang Tuan Long, Nguyen Dinh Tien, Le Manh Thang, Nong Hong Hanh, Dang Thuy Nga (2018). Impacts of Payments for Forest Environmental Services (PFES) in Son La, Vietnam. Report No.188. Bogor, Indonesia: CIFOR.

9. Pham Thu Thuy, Dao Thi Linh Chi, Nguyen Thanh Long, Hoang Tuan Long, Nguyen Dinh Thao, Pham Hong Luong (2020). Impacts of Payments for Forest Environmental Services (PFES) in Cat Tien National Park. Report No. 215. Bogor, Indonesia: CIFOR.

10. Pham Thu Thuy, Loft, L., Bennett, K., Phuong, V. T., \& Brunner, J. (2015). Monitoring and evaluation of Payment for Forest Environmental Services in Vietnam: From myth to reality. Ecosystem services, 16, 220-229. doi: https://doi.org/10.1016/j.ecoser.2015.10.016.

11. Thu-Ha Dang Phan, Roy Brouwer, Long Phi Hoang, Marc David Davidson (2018). Do payments for forest ecosystem services generate double dividends? An integrated impact assessment of Vietnam's PES program. Truy cập từ PLOS ONE | https://doi.org/10.1371/journal.pone.0200881 ngày 10 tháng 5 năm 2021.

12. To P. \& W. Dressler (2019). Rethinking 'Success': The politics of payment for forest ecosystem services in Vietnam. Land Use Policy. 81: 582-593.

13. Tran Huu Tuan, Bui Duc Tinh, Tran Van Giai Phong (2012). Economic, social and environmental impacts of PFES pilot program in Lam Dong. Electronic Journal of Science and Technology. Da Nang University. 8 (57).

14. Tran Xuan Tam (2017). Policy on payment for forest environmental services with livelihoods of people in the buffer zone of Muong Nhe Nature Reserve. Assessed from http://tapchimoitruong.vn/pages/article.aspx?item=Ch\%C3\% Dated ${ }^{\text {th }}$ July 2020.

15. Trung Thanh Nguyen, Van Dien Pham \& T. John (2013). Linking regional land use and payments for forest hydrological services: A case study of Hoa Binh Reservoir in Vietnam. Land Use Policy 33: 130-140.

16. Vuong Van Quynh \& Tran Thi Trang (2018). Value of forest environmental services for hydropower in Vietnam. Workshop on Forestry Development in Vietnam: Opportunities, Challenges and Solutions. $176-183$.

17. Wichelns, D., Milan, F., Hoanh, C. T., \& Phuong, N. D. (2016). Household opportunity costs of protecting and developing forest lands in Son La and Hoa Binh Provinces, Vietnam. International Journal of the Commons, 10(2), 902-928. doi: http://doi.org/10.18352/ijc.620.

Cite this Article: Nguyen Phuong Le, Mai Quyen, Nguyen Mau Dung (2021). Assessing Impacts of Payment for Forest Environmental Service Policy in Hoa Binh Province, Vietnam. International Journal of Current Science Research and Review, 4(6), 548-555 